\title{
Sfinkterskader under fødselen kan reduseres
}

\section{Skånsomme forløsningsmetoder kan halvere forekomsten av fødsels- relaterte skader på endetarmens lukkemuskel.}

Skader på endetarmens lukkemuskel kan skje under vaginal fødsel. Skadefrekvensen varierer mellom land og mellom fødeinstitusjoner. Slik sfinkterskade skjer ved 1-6\% av vaginale fødsler. Skaden kan føre til analinkontinens, dvs. ufrivillig lekkasje av luft eller avføring - svært ubehagelige plager som kan gi sosiale og hygieniske problemer samt redusert livskvalitet. I tillegg til analinkontinens kan denne fødselsskaden forårsake smerte, ubehag og seksuell dysfunksjon.

Jeg har i min doktoravhandling undersøkt forekomst av og tiltak for å forebygge fødselsrelaterte skader på endetarmens lukkemuskel. Avhandlingen er basert på tall fra fødeavdelingen ved Oslo universitetssykehus, Ullevål, fra periodene 2003-05 og 2005-10. Mellom de to periodene ble det gjennomført et opplæringsprogram for fødselshjelperne ved avdelingen, slik at man kunne gi bedre perineumstøtte under utdrivningsfasen. Ved sammenlikning av de to periodene fant vi at forekomsten av fødselsrelaterte sfinkterskader var halvert. Kvinner som ble forløst med keisersnitt eller som fødte før uke 32 av svangerskapet ble ikke inkludert. Det var ingen signifikante forskjeller mellom kvinnene som fødte i første periode og kvinnene som fødte i andre.

Jeg fant også at den selvrapporterte forekomsten av analinkontinens hos gravide var betydelig høyere hos dem som hadde fătt sfinkterskade ved en tidligere fødsel (24\%) enn hos dem som ikke hadde fått slik skade.

Funnene mine tyder på at forbedrede forløsningsteknikker fører til færre lukkemuskelskader. Færre slike skader vil trolig redusere forekomsten av analinkontinens hos kvinner i fertil alder. Dette kan ha en positiv effekt for kvinners helse både på kort og på lang sikt.

\section{Katariina Laine}

h.k.laine@medisin.uio.no

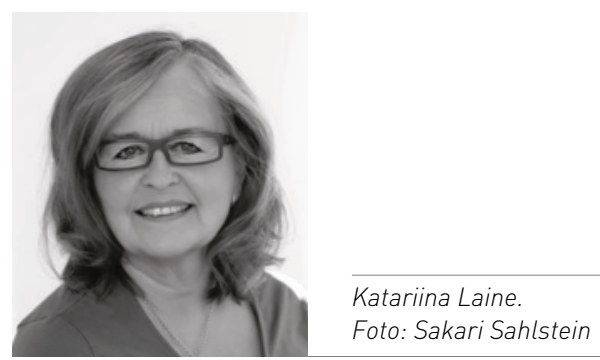

Disputas

Katariina Laine disputerte for ph.d.-graden ved Universitetet i Oslo 30.10. 2013. Tittelen på avhandlingen er Obstetric anal sphincter injuries: incidence, risk factors, consequences and prevention.

\section{Rent oksygen gir økt skadeomfang}

\section{Eksponering for rent oksygen etter hypoksisk-iskemisk hjerneskade ga mye større skade hos nyfødte rotter enn eksponering for romluft.}

Barn som er født for tidlig, er spesielt utsatt for hypoksisk-iskemisk hjerneskade. Ved reperfusjon vil det dannes oksygenradikaler, noe som gir oksidativt stress. Det nyfødte barnets hjerne er spesielt utsatt for slikt stress, og det er mulig at ekstra oksygentilførsel i reperfusjonsfasen øker skadeomfanget. Ifølge gjeldende retningslinjer anbefales det derfor å starte gjenoppliving av barn født til termin med romluft i stedet for rent oksygen, men det er lite bevisgrunnlag for en klar anbefaling når det gjelder for tidlig fødte.

I min doktorgrad undersøkte vi hvordan eksponering for rent oksygen påvirker skadeomfanget over tid i nyfødte rotter med hypoksisk-iskemisk hjerneskade. Det ble gjort ved hjelp av MR-avbildning fra skadetidspunktet og frem til nær voksen alder.

Rent oksygen ga sterkt økt omfang av hjerneskade sammenliknet med romluft, og forskjellen økte over tid. Hjernens utvik- lingsstadium i modellen er sammenliknbar med den hos barn født i svangerskapsuke 32-34. Vi undersøkte også hvordan nedbrytning av glukose via pentose-fosfatshunten påvirkes av hypoksisk-iskemisk hjerneskade. Pentose-fosfat-shunten opprettholder nivået av antioksidanter i hjernen, og i voksen hjerne kanaliseres mer glukose via denne shunten ved oksidativt stress. Hos nyfødte fant vi at andelen glukose metabolisert via pentose-fosfat-shunten ble nedregulert etter hypoksisk-iskemisk hjerneskade.

Resultatene viser at det er viktig å utvise forsiktighet med å gi høye nivåer av oksygen til for tidlig fødte barn ved gjenoppliving etter hypoksisk-iskemisk hjerneskade. Manipulering av pentose-fosfat-shunten kan representere en potensiell fremtidig behandling.

Tora Sund Morken

tora.s.morken@ntnu.no

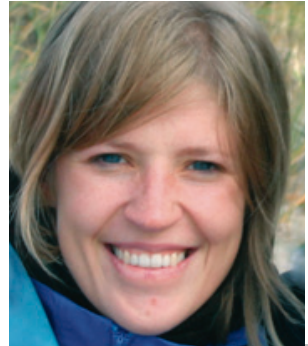

Tora Sund Morken Foto: Privat

Disputas

Tora Sund Morken disputerte for ph.d.-graden ved Norges teknisk-naturvitenskapelige universitet 9.12. 2013. Tittelen på avhandlingen er Brain development and metabolism after hypoxiaischemia and varying oxygen levels in the neonatal rat studied with ${ }^{13} \mathrm{C}-\mathrm{MR}$ spectroscopy and multimodal MR imaging. 